TEME, г. XLIV, бр. 3, јул - септембар 2020, стр. 863-880

\begin{tabular}{lr}
\hline \hline Претходно саопштење & https://doi.org/10.22190/TEME190117050N \\
Примљено: 17.1 .2019$. & UDK 159.955.5:[29:371.4
\end{tabular}

Ревидирана верзија: 20. 9. 2020.

Одобрено за штампу: 1. 10. 2020.

\title{
CRITICAL THINKING BETWEEN ESSENTIALISM AND PERENNIALISM
}

\author{
Ivan Nikolić \\ University of Niš, Faculty of Philosophy, Niš, Serbia \\ ivan.nikolic@filfak.ni.ac.rs
}

\begin{abstract}
The intention of the author of this text is to explore deeply the meaning of the concept of critical thinking from the perspective of teaching philosophy. For the purpose, he concludes that the best point for developing critical thinking in the field of philosophy is actually between essentialism and perennialism. Starting from the assumption that philosophy, by teaching critical thinking, teaches students to be 'rational judges' and on the other hand 'sensitive to context', the author concludes that having skills and a developed attitude are equally important for such education. Educational essentialism will be observed from the point of view of the development of pre-reflective intentionality, by teaching logical and methodological structuring of problems, and educational perennialism as directing to the most important concepts of solving certain problems.
\end{abstract}

Key words: critical thinking, skills, attitude, essentialism, perennialism.

\section{КРИТИЧКО МИШЉЕЊЕ ИЗМЕЪУ ЕСЕНЦИЈАЛИЗМА И ПЕРЕНИЈАЛИЗМА}

\section{Апстракт}

Намера аутора овог рада је да дубље истражи значење концепта критичког мишљења из перспективе поучавања филозофије. У ту сврху закључује да је најбоља позиција за развој критичког мишљења у области филозофије заправо на граници између есенцијализма и перенијализма. Полазећи од претпоставке да филозофија, поучавајући критичком мишљењу, образује ученике да постану, с једне стране, 'рационалне судије', а са друге да буду 'осетљиви на контекст', аутор закључује како поседовање вештина и развијен став имају подједнаког удела у оваквом образовању. Из те перспективе, образовни есенцијализам ће бити посматран као развој пререфлексивне интенције кроз поучавање логичком и методолошком структурисању проблема, а образовни перенијализам као упућивање у најзначајније концепте решавања извесних проблема.

Кључне речи: критичко мишљење, вештине, став, есенцијализам, перенијализам. 


\section{INTRODUCTION}

The curricula, as we find them in contemporary teaching practice, inevitably favor the development of critical thinking as the ultimate educative aim. Such state is characteristic not only for humanities, but for natural sciences as well. However, for philosophy, teaching this state is even more important, if the mere philosophy from its beginnings is viewed through the concept of the development of critical thinking. Sometimes implicit, sometimes explicit, the focus on developing the ability with students, readers, listeners, of what is nowadays called intentional learning that characterizes, "self-awareness, active monitoring of the learning process, and a desire for publicly certified expertise" (Cholbi 2007, 35) is present in the philosophy since its beginnings. As Hare notices:

"In fact, the history of this ideal can be traced back through philosophy to the earliest time. That account would include references to Mill on keeping one's eye open to criticism, $[\ldots]$ and on through the history of philosophy to its origins in the Western tradition, at least, in the Socratic emphasis on the examined life" (Hare 1999, 86).

From such a perspective, the philosophy itself, through its history, testifies to the development of, ultimately, an attempt to develop critical thinking. So, as teachers in philosophy, we are obliged to elaborate which in our opinion is the best explanation of this concept. We believe, and will try to demonstrate it further, that for the development of critical thinking seen in such a way, the educative position is the best starting position, in between essentialism and perennialism.

\section{CRITICAL THINKING BETWEEN SKILLS AND ATTITUDE}

The term 'critical thinking' is to a great extent elaborated - very precisely and with a lot of examples and literature related to it. This generally makes our work more difficult because it is good to break through more concepts that define and elaborate on what critical thinking is. As philosophy teachers, we are in the position to act according to Malmgren's, Trezek's and Paul's advice that says:

"The important point is for teachers to educate themselves about the various models and choose the one (or combination of ones) that mesh best with their teaching philosophies and personalities" (Malmgren, Trezek and Paul 2005, 38).

Led by such advice, we will try to crystalize anew the domain in which the determination of critical thinking moves, and to eventually give our perception of the concept.

Primarily, critical thinking is a process, an open process, open activity, that should lead one who is educated in philosophy towards a specific attitude 
- one that Hare defines as 'open mindedness'. On the other hand, it is at the same time a skill, so to say, a craft, that follows such an attitude. To put it simply, this openness of thinking protects critical thinking from the threat of a 'dogmatic agitation', but also, the skills prevent the critical thinking to turn into a 'verbal exhibition'. ${ }^{1}$ Why do we call critical thinking an open activity? Namely, Stella Cottrell defines critical thinking as follows: "Critical thinking is a cognitive activity, associated with using the mind" (Cottrell 2005, 1). Still, it appears that she sees the process of critical thinking from a significantly broader angle, since she also takes into consideration the reasons that stand in the way of that development, and which we cannot call strictly cognitive. For that purpose, she elaborates on the overcoming of affective, social and emotional factors, and with the aim to reach something that she will define as 'capacity for rational thought'. Seeing critical thinking as a strictly cognitive process coincides more with the explanation given by Bowell and Kemp when they take the term 'critical reasoning' (Bowell and Kemp 2005, vii) as synonymous to the critical thinking. Having in mind the previous, we are inclined to see critical thinking initially as not strictly cognitive, but as an open process, which we will eventually try to elaborate further in the paper.

With the previously stated, it is already clear that the conceptions of critical thinking can be divided generally, according to the authors that favor skills, on one hand, and those who favor attitude, on the other. While the first will give more importance to education in logics and methodology (finding premises, drawing conclusions, differentiating between good and bad conclusions, insights into logical mistakes, etc.), the latter will believe that what is crucial for critical thinking is character, disposition (doubt, manageability in concrete situation, creativity, etc.). It should not be neglected that both take into consideration skills and attitude, but the difference between them is found in what they, a bit awkwardly, consider, as noticed by Mason on Paul's trace, as critical thinking in a weak sense and critical thinking in a strong sense (Mason 2008, 3) (Paul and Elder 2002, 45). What is strong and what is weak in the previous division of viewpoints depends on giving priority either to skill or to disposition.

Not wanting to take either of the sides, we can say that both of them have the right to promote this or that side of critical thinking depending on the domain in which they should be applied. Some of them, already mentioned (Cottrell, Bowell, Kemp and Paul ${ }^{2}$ ) count on the universal power of skills, so their books look like manuals from all the areas of

\footnotetext{
${ }^{1}$ See: (Marinkovic 1990, 16-17)

${ }^{2}$ It should be noticed that Phelan will categorize Paul in the midland between these two groups of critical thinkers, but with the statement that: "Paul's work falls short when it comes to "the rough ground"' (Phelan 2001, 43) it will mark that it stills inclines to logical formalism.
} 
human activity ${ }^{3}$. Therefore, as already noticed, springs their rigid connection to formal logics, because in the end: "it highlights the intellectual dimension of thinking" (Paul and Elder 2002, 106). However, although focused on all the areas of human activity, critical thinking defined in such a way is not equally successful in them, which will be the main objection of the other side in seeing critical thinking. On the other side, there are authors such as Thayer-Bacon, Alston, Phelan, etc. From their perspective, the practical side of the use of critical thinking is emphasized. It is clear that the first ones also rely on this use, but still it appears, as noticed by Alston:

"critical thinking that reads arguments, texts, or practices merely on the surface without connections to feeling/desiring/doing or action lacks an ethical depth that should infuse the difference between mere cognitive activity and something we want to call critical thinking" (Alston 2001, 34).

Representatives of the opposite side, when it comes to seeing critical thinking, largely rely on Aristotle's definitions presented in his Nichomachean Ethics.

At the beginning of the mentioned book, Aristotle implicitly emphasizes the necessity of a lifetime experience in order to obtain certain knowledge, primarily political and ethical. Thus, cognitive skills, by themselves, do not guarantee the success in acting since the knowledge in this field requires maturity as well. Following this line of thought, young people or people who can be called such do not reach 'practical wisdom':

"because of his tendency to follow his feelings, his studies will be useless and to no purpose, since the end of the study is not knowledge but action" (Aristotle 2004, 5).

Aristotle, further on, points that action seen in this, practical light,

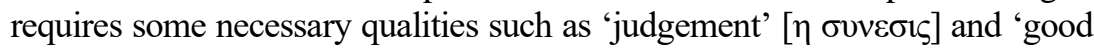
judgement' $[\eta$ $\varepsilon v \sigma v v \varepsilon \sigma i \alpha]$, but these qualities are not sufficient to reach practical wisdom $[\eta \varphi \rho o v \eta \sigma \iota \varsigma]^{4}$. It is evident that Aristotle views the relation between 'judgment' and 'practical wisdom' in two ways. Namely, he states that 'judgment': "is neither the possession nor the acquisition of practical wisdom" (Aristotle 2004, 114), which can lead to the conclusion that we connect these two characteristics without any basis for doing so. Still, the basis for connecting them can be found in one of Aristotle's statements, according to which, judgment is: "involved in employing belief to judge what someone else says about what concerns practical wisdom" (Aristotle 2004, 114). If we interpret this from the viewpoint of Alston's previous statement

\footnotetext{
${ }^{3}$ Let's say that in the subtitle of Paul's book, we read 'A Guide for Improving Every Aspect of Your Life' or 'Tools for Taking Charge of Your Professional and Personal Life'

${ }^{4}$ Some authors translate this term also as 'deliberation'.
} 
about determining critical thought, then we can say that, in order to be complete, it needs to be developed not only in the direction of 'good judgment', but also in the direction of 'practical wisdom'.

Actually, one more key characteristic necessary for critical thinking is pointed out here, and that is 'practical wisdom'. Although from the position of ethics, this Aristotle's conception is elaborated significantly more complexly and more elaborately, we will stay in the frames of its presentation seen from the perspective of critical thinking. Thus, as stated by Carr and Kemmis, from a broader perspective, practical wisdom is reduced to: "a prudent understanding what should be done in practical situation" (Carr and Kemmis 2004, 132), and more narrowly to a disposition connected to a person who: "interprets the world reflectively," and who is aware: "of values to which she or he is committed, the values commitments of others, and those fostered by contemporary culture" (Carr and Kemmis 2004, 93). Therefore, the advocates of the opposite line of thought will tend to favor human knowledge which depends on seeing that we have:

"certainly greatly affected by our communities, indeed we learn our language and our culture, even our sense of who we are as individuals throughout our communities" (Thayer-Bacon 2001, 6).

From the perspective of general education theory, as defined by Kant, there are four objectives that should be developed with students: 'to be disciplined', 'to be cultivated', 'to be civilized' and 'to be moralized'. Having in mind the mentioned, and implicating the members of the other line of thought in defining a critical thinking again, it seems that out of the four objectives, they consider the most important one 'to be civilized'. And indeed, if we should develop a disposition commitment towards others who surround us and towards contemporary culture, then the ultimate purpose of that can be seen as what Kant understands as be: "well suited for human society, popular, and influential" (Kant 2007, 444). If we leave aside popularity and influence, we really move in the world which we approach through language, manners, culture that the world imposes on us, and it is almost impossible to function unless certain discipline in that world is developed. Returning to Kant and his thinking, we really cannot make a step towards other objectives unless we are previously disciplined in the sense: "to prevent animality from doing damage to humanity," and unless we are cultivated in the broadest sense according to which we should possess certain skills that are: "good in all cases, for example reading and writing" (Kant 2007, 444).

From all previously mentioned, it can be concluded that 'critical thinking' might be better seen as 'constructive thinking', but in a broader sense than it is taken by Thayer-Bacon. Namely, she develops the meaning of

${ }^{5}$ See: (Kant 2007, 444) 
this term on the platform of meaning that Belenky and others attribute to the term 'constructive knowledge'. ${ }^{6}$ The point being that our knowledge, and therefore our thinking, is primarily constructed as a socio-cultural phenomenon. We certainly will not dissociate from such thinking, but we still hold that constructive thinking, apart from being constructed, should also be constructive. In conclusion, if philosophy: "should be motivated by a concern for a more humane and just world" (Mason 2008, 5), then it should be able to construct the world initially on the meta level. From that perspective, it is necessary to have creativity to overcome the already constructed and familiar socio-cultural schemes, and we can say also the scientific ones. 'Constructions' by Bolyai and Lobachevsky, Einstain and other great thinkers in science are sufficient proof that critical thinking relies on the creation of new systems. We, of course, as philosophy teacher will not set such ideal schemes of critical thinking as the ultimate objective, but we will be satisfied with the concept of the development of creativity and constructivity as seen in one narrow meaning.

As Hanson notices: "the distinction between creativity and innovation is not often made" (Hanson 2015, 22). Furthermore, he will say that the definition of creativity as: "producing a thing or an idea that is novel and valuable in its context" (Hanson 2015, 24) has reached a deadlock. That can be seen from his observations in which he notices new definitions of creativity, where the term 'novel' is substituted with 'original' and the term 'valuable' with terms 'useful' or 'adaptive'. So, it is obvious that the acceptability of the definition of creativity in contemporary context actually lies in the softening of what creativity really means in an ideal sense. In this sense we will try to distance ourselves from creativity as innovation, and when we talk about critical thinking and its creative potential, we have in mind what we consider 'original' and 'adaptive'. Our position of acting also obliges us to approach the issue in this manner. Owing to the fact that we have in front of us the material that is given, be it through history of philosophy or through ethical or aesthetic problems, we as philosophy teachers tend to develop original interpretations of philosophical systems (opposite to what would be a mere acceptance of someone's interpretation) and 'adaptability' of such interpretations in one or other contexts. On a deeper level, the limitation of creativity is related to what theoreticians of creativity call 'pre-reflexive intentionality'.

The stated term assumes certain social skills that enable: "realization of the capacity to act" (Ballantine 2007, 154). From the domain of philosophy those skills will reflect in the possibility to structure an opinion on this or that problem. That structure is situated in our western philosophical

\footnotetext{
${ }^{6}$ In the source which Thyer-Bacon refers to, it says 'constructed knowledge'. See: (Belenky, et al. 1997, 131-155)
} 
tradition in what we call "classical sentential logic' ${ }^{7}$ and 'philosophical methodology'. ${ }^{8}$ No matter that, on Kant's trace, we have already defined that every progress in the society requires certain discipline such as the ability to read and write, then such discipline in philosophy reflects through the structuring of reading, writing and making conclusions in the manner of such logics and methodology. On the other hand, if we express it through the prism of Aristotle's teaching, if practical acting necessarily requires disposition ' $\eta \varphi \rho o v \eta \sigma \iota \varsigma$ ' then it is only possible on the platform of

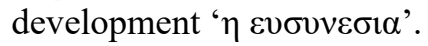

Now it is time to make another digression. Namely, the term 'prereflexive intentionality' should be additionally explained from the perspective of our perception of the problem. The use of the coined term 'pre-reflexive intention' might suggest a structure leading to intentionality, potentiated through the first part of the coined term 'the pre-reflexive'. On the base of the theoretical conceptual achievements offered by Joas, Touraine and Ricoeur, Ballantine sees this problem, the problem of the pre-reflexive intention, hermeneutically and pragmatically. Still, we go through this interpretation following Evers' trace by which: "we cannot impute intentional behavior without also imputing a large amount of rationality to people's words, thoughts and behavior" (Evers 2008, 28). Therefore, our interpretation moves in the other direction, the opposite of Ballantine's. It is true that we perceive the function of the critically-thinking subject at the border between the rule of "immanent to practices in the form of constitutive rules" and what we can determine as "the orientations which constitute the horizon of action" (Ballantine 2007, 158). However, the mentioned pre-reflexive, here, we relate only to the first part of the limitation. So as to additionally enlighten our position, let us start from the very definition as it is found in Brentano's work and try to analyze it. Namely, Brentano's definition of intentionality is a:

"direction toward an object... In presentation something is presented, in judgment something is affirmed or denied, in love loved, in hate hated, in desire desired and so on" (Brentano 1995, 68).

Considering the former, it is not hard to understand that our analysis refers to the part which states 'in judgment something is affirmed or denied'. Of course, we judge many things, and bear in mind various horizons, which can carry the judging process, but what is important is that the judging must

\footnotetext{
${ }^{7}$ See: (Burgess 2009, 1-13)

${ }^{8}$ It is also possible to observe these two philosophical fields from the perspective of the development of dialogic logic which, unlike sentential logic, views premises as hypotheses, and then demands that the defensibility of an expressed opinion be conducted: "in relation to a particular constellation of argumentative statements" (van Eemeren and Grootendorst 1984, 13). Thus, in a way, it encompasses both of the previously mentioned philosophical fields.
} 
be clearly structured and, for the time being, offer one basic codification which includes skills in logic and methodology. Let us conclude this short digression. It is evident that by thinking about a problem, we delve deep into the pattern for interpretation, but for the beginning, that interpretational pattern must be structured logically and methodologically.

Finally, we reach the definition that fits the best in our presented vision of critical thinking. It is the definition stated by Hare, and it goes as follows:

"Critical thinking is thinking that facilitates judgment because it relies on criteria, is self-correcting and is sensitive to context" (Hare 1999, 87).

In the domain of what is defined as 'to facilitate judgement', the crucial role will belong to the strengthening of 'pre-reflexive intention' through education in logics and methodology. However, the 'pre', we say it again, is seen here as a formation of the rational 'pre' judgement and in this sense it is alleviating to judgement. From that perspective, logics and methodology can influence the second item in the development of critical thinking, i.e. the 'self-correcting' but only within a limited domain. The second crucial thing for 'self-correcting' lies in the development of 'sensitivity to context'. Exactly here we, as philosophy teachers find ourselves on slippery grounds. Namely, it is not about a mere recognition of the context, but about the readiness that certain problems, even though logic and methodologically might be well structured, do not provide final answers, so if this feature should be attached to some definition it can be found in the disposition: "to address questions which are more complicated and sophisticated, and which do not lend themselves to straightforward responses" (Cottrell 2005, 9).

\section{EXAMPLE}

As a philosophy teacher I often find myself in the position to discuss the term 'critical thinking' with my students. As I always tend to bring to surface all the issues and terms through discussion and debate, initially I strive to provide them with an insight into what the necessary skills are. With that intention, the task that I put in front of them is to watch the movie 12 Angry Men by Sidney Lumet (1957), before the class. Trying to recognize what the main hero from the movie does by giving argumentation in favor of the convict, we actually learn about the skills necessary for righteousness, and, at the same time, about the strength of argumentation. Namely, the main hero is equally skillful in sophisticated perception, in calculation, knowing the character, rationalization and other techniques, so in conclusion there is no doubt left in the righteousness of the final decision at the benefit of the acquittal. And indeed, observed in isolation to other versions, 
independently, this movie is a dedication to the skills and possibility of 'self-correctness' rather a space for the other part of critical thinking, i.e. 'sensitivity to context'. At first, it might appear that after seeing the movie there is no space for further development of critical thinking. Still, very soon, what seemed to be a closed and well formatted decision, by means of 'scandalon', is placed on the slippery terrain of doubt. The next task that I give to my students is to watch the movie ' 12 ' by Nikita Mikhalcov, which represents the remake of the previous movie, and in such a way I create a field for a vigorous debate about the correctness of the decision. The first context is presented through the inscription "Administration of justice is the firmest pillar of good", and the second one through the quotation from the beginning of Mikhalcov's movie "Не следует здесь правду быта, попытайтесь ощутить истину бытия". The Nikita Mikhalcov movie is even more inspiring if in the last minutes it completely twists the conviction in the previously made decision about the liberation of the convict. Perceived through the prism of critical thinking, the skillful running of the debate can lead to a seemingly correct decision, but not always and not necessarily. The broader context, the context of the existence or broader perception of reality can override the decision no matter how rationally it may seem correct.

If we start from the assumptions that the correct teaching of philosophy follows the trace from the particularly viewed problems through aesthetics, ethics, anthropology to those general ontological and epistemological, then we come to a higher form of debate that no longer applies only to the correct decision from the position of the law and regulations, but from the positions of true knowledge of reality, i.e. the existence as suggested by the inscription from the beginning of Mikhalcov's movie.

Before we start deliberating this example through the prism of the previously mentioned claims, it can be noticed that it is not about the analysis of the classic philosophical texts, but rather about setting the kinds of thought experiments made by the creators of these films ${ }^{10}$. It is noted that in the modern educational practice, the significance of these thought experiments is more emphasized, which:

\footnotetext{
9 "Do not try to find the justice of life here, try to learn the truth of the existence."

${ }^{10}$ More specifically, including a film as a platform on which numerous philosophical problems can be deliberated, is seen by comparing two philosophical books which are used in Serbian educational system. Namely, the former, published in 2001. still includes classic philosophical sources. The latter, published in 2016. by, actually, a foreign publisher, provides with every unit numerous other sources, such as film, for the purpose of better understanding philosophical problems and their possible solutions. It appears that in the western educational practice the importance of this manner of transferring philosophical material is spotted significantly earlier, which is proven by books such as Baggini's The Pig that Wants to be Eaten or Law's the Philosophical Files.
} 


\begin{abstract}
"opens the gates of crossed, ornate, unpredictable paths in the gardens of thinking, bringing us into fun labyrinths of deduction of questions and intellectual conundrums" (Bogdanovski 2018, 34).
\end{abstract}

It is thought as well that these experiments fit into the previously stated note of Stella Cottrell, so, they are sufficiently complicated and sophisticated for further philosophical exploration. As philosophy professors, we support, to a great extent, such way of development of the modern practice of teaching philosophy because we believe that in this way students are easily initiated for recognizing philosophical problems and concepts which are in their basis.

Returning to the deliberation of the previous example, after a short digression, we will notice that it creates space for a conflict of two contexts. Namely, in the broadest sense, it is about the conflict of two points of view. One is inspired by Lumet's movie, the other by Mikhalkov's. Naturally, if the point of critical thinking is to avoid the trap of 'dogmatic agitation', as it was previously stated, expressing in the way of either point of view has to be supported by suitable argumentation. However, when it comes to a hard case in legal practice, which this example tries to illustrate, arguments in favor of either viewpoint have to go deeper into the moral principles which give the basis to either of the points of view. Discussing this we consider solutions which are suggested for these cases by Dworkin in his book Taking Rights Seriously. He claims that:

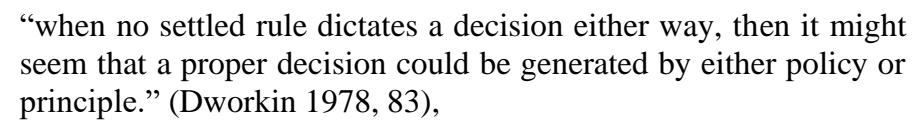

and further on suggests that: "the thesis that judicial decisions in civil cases [...] characteristically are and should be generated by principle not policy" (Dworkin 1978, 84). So, beneath the originally set layer, it would be good to reveal the deeper layer which concerns principal argumentation, and whose revealing actually leads to stronger argumentative power and easier deciding in hard cases. Of course, it is clear that referring to Dworkin suggests that these ways of argumentation are introduced on the platform of philosophy of the law, but we will try to explore them for the purpose of explaining the position of critical thinking between essentialism and perennialism. Let's try to explain that more precisely.

At first, through discussion about two offered viewpoints, the first dissociative is created, which can be seen, in the broadest sense, through the conflict of 'legal positivism' and 'natural law'. At this level, already, in defense of either position, principal reasons are involved, so that the one broader argumentation gradually becomes principal argumentation, for the purpose of strengthening represented positions. Philosophically speaking, that transition is viewed in the response to whether law should be based on morals or not. If it should, then the argumentation is constructed in the ethical context. Therefore, what is important to notice for the extents of this 
text is that the excuse does not go in the direction of making up new viewpoints but in the more original understanding of the moral principles on which they are based on. All of this is concerned with our understanding of what Hare called 'sensitivity to context'. Actually, we will notice that for development of critical thinking, whether in the juridical or the ethical domain, it is necessary for students to acquire and use certain information from legal ideologies and ethical concepts related to the problematics which is being discussed. However, the sensitivity to context, should it be included in a well conducted debate, implies a hypothesis which requires students to be, as Dworkin from another perspective states, 'reasonable lawyers'. On the other hand, one should be familiar with a variety of concepts, in this case juridical and ethical, but the power of deciding to accept one or the other lies in rationality, reasonable argumentation pro et contra those concepts.

What can be assumed from the previous is the fact that our determination of the development of critical thinking has been moving in the domain of equal study of skills and bringing the students to the position of a 'reasonable lawyer', as well as strengthening sensitivity to context. The latter assumes the possibility to first recognize the concepts and their applications to the given problem, followed by the selection of the concept that is most suitable for solving the given problem. As we have already pointed out, on the one hand, this is done in order to avoid verbal exhibition, and to avoid indoctrination and consequent enculturation, on the other ${ }^{11}$. When we are in the domain of the first goal, it is imperative to maintain discipline in expressing any opinion related to any problem. Therefore, it might be better to view the expression extracted from the philosophy of law from the perspective of the entire argumentative theory, and, in effect, use the term "rational judge" 12 .

Of course, this connection between the 'reasonable lawyer' position and the 'rational judge' position requires a deeper analysis. It is certain, however, that both positions have in mind the reference to the principles as we mentioned it on Dworkin's trace, and certainly these principles should be rational, but the question that we would ask here would be: 'are the principles on which we rely on always the same?' or, more precisely, 'can we count on their universality?' It seems that it is not that simple and it should be explained further. Let us first begin by distinguishing between the adjectives that follow these positions. In one domain the terms 'reasonable' and 'rational' are taken as synonyms so that from information such as: "behaves in a sensible and fair way" and: "based on sensible practical reasons rather than emotions" (Macmillan Dictionary n.d.) we

\footnotetext{
${ }^{11}$ See: (Gatchel 2010)

${ }^{12}$ See: (van Eemeren and Grootendorst 1984, 5)
} 
cannot see any more precise difference. Also, it is noteworthy that two dictionaries (Macmillan's and Longman's) attach the term 'reasonable' to the description 'not very good' in the first case, and 'not especially good' in the second case, which can in fact be taken as a suggestion that the principles for 'reasonable lawyer' are flexible and depend on case by case basis. If, however, we start from rational behavior ("the formal ability to make sensible judgements" (Longman Dictionary of Contemporary English n.d.), we realize that the principle can be found in a certain form, which again does not give the final answer to our question. We think that from this side of the observation of the problem the interpretation of Habermas can help us.

Namely, from the beginning of his work, in which the subtitle stands Reason and The Rationalization of Society, Habermas gives one, for our present exploration, very important division. Namely, he recognizes three forms of rationality related to three domains of philosophical problems. These are 'cognitive rationality', then 'moral-practical' and finally 'aesthetic-practical' rationality ${ }^{13}$. From this perspective, we can conclude that the 'reasonable lawyer' position is in the domain of 'moral-practical' rationality. By going further, we can say that the position of the one who concludes about natural facts is in the domain of 'cognitive rationality'. Someone who would discuss aesthetic concepts, which we did not explicitly set out, would come from the domain of 'aesthetic-practical' rationality. Our further exposition will be depleted by attempting to connect these two groups of rationality, cognitive and practical, in order to justify the educational position from which critical thinking should be developed, and that position, as it has been emphasized several times, is in between essentialism and perennialism.

It is not hard to notice that, indeed, some of the above-mentioned forms of rationality fully find their meaning if they are applied partially to some of the problems. It is clear that in mathematics, physics, chemistry, etc., as separate disciplines, the primary place belongs to 'cognitive rationality'. However, this type of rationality is not sufficient in ethical and aesthetic discussions. Let us take, as an example, Descartes who bases his Regulae and Discourse on the application of this kind of rationality. It is certain that when it comes to mathematical problems of ratio, proportions, etc., this kind of rationality really finds its application ${ }^{14}$. On the other hand, when Descartes tries to introduce us to family relationships using the same rationality, then it really seems insufficient ${ }^{15}$. Also, his reference to the rules of provisional morality is perceived only as a mere statement, rather

\footnotetext{
${ }^{13}$ See: (Habermas 1984, 3)

${ }^{14}$ See: (Descartes, Regulae ad directionem ingenii - Rules for The Direction of The Natural Intelligence 1998, 100-105)

${ }^{15}$ See: (Descartes, Regulae ad directionem ingenii - Rules for The Direction of The Natural Intelligence 1998, 191-193)
} 
than as a rationally based ethical concept ${ }^{16}$. This leads us to the conclusion that 'cognitive rationality', seen as it is in the sphere of ethics and aesthetics, is insufficient and requires a certain complement, in other words, requires another kind of rationality. At the very end, as it was concluded by Habermas, this kind of rationality: "excluded moral-practical questions of legitimacy from scientific consideration" (Habermas 1984, 3).

The same, only reversible, we can notice as well when it comes to the application of 'moral-practical' rationality. In this respect, we can be interested in the way in which Galileo defends the settings of Copernicus's heliocentric system. Having such a task in mind, Galileo gives a partially new platform for analyzing the Holy Scriptures. His first intention is expressed through the separation of astronomical from theological issues. From this perspective, Galileo discerns that the Bible from the perspective of theological questions: "must be interpreted differently from the apparent meaning of the word" (Galilej 2010, 15), but immediately afterwards, and with regard to the interpretation of nature, he adds that theological interpretations must not:

"in a certain way, claim that some conclusions about nature are true, which the reason and necessary considerations in the form of evidence would present to us as the opposite" (Galileo 2010, 17).

For the purpose of interpreting nature, it must be treated in the manner of 'cognitive rationality'. Therefore, it should not be surprising that Galileo's argument finds its affirmation, for example, in the case of Aristotle's teaching about movement (Evers 2008, 33), that is, in the domain of Aristotle's physical considerations. However, we cannot count on this kind of rationality when we consider ethics and aesthetics.

It is clear that Descartes' and Galileo's application of rationality is limited to the domain of one world, the world of nature. In Galileo's case, this is explicitly visible, while Descartes' position fades to a metaphysical foundation, which is essentially mathematical-theological. Whatever the case, Descartes uses his key considerations as the base to reach the fundament perceived in this way; begins with the establishment of a hierarchy of natural sciences. The structure that Descartes sets forth starts with the doctrines of the rerum compositarum, such as "physics, astronomy, medicine, and all other disciplines that involve the study of composite things" (Descartes, Meditations on First Philosophy 2008, 15), which points us to the conclusion that he derives his metaphysical and theoretical attitudes from the perception of natural reality. This is said in order to be completely accurate. Descartes' idea of the subjective certainty of knowledge fits into what Heidegger later

${ }^{16}$ See: (Descartes, A Discourse on the Method 2006, 21-25) 
calls 'mathematical physics' ${ }^{17}$. From our perspective, one can draw the conclusion that this form of strictly 'cognitive rationality' is utterly depleted when applied in the description of natural objects, but it is visibly defective when it extends to the field of ethical and aesthetic problems.

The scope of this problem can also be interpreted from the position of contemporary American theory of debates. Namely, the difference between the aforementioned forms of rationality can be explained by the claim: "American debate distinguishes between three types of propositions: propositions of fact, propositions of value and propositions of policy" (Houtlosser 2001, 39). Further, Houtlosser finds that there are 'stock issues' in the field of such propositions, which: "should be addressed in defending the proposition" (Houtlosser 2001, 39). Through this prism we see that these stock issues actually refer to the context in which the proposition is expressed and that, in fact, this context dictates which rationality should be applied. However, although this additional distinction clarifies the difference between the different types of rationality, it does not lead us to solve the problem we have set. The only thing that Houtlosser brings out, and what can serve as a link in the chain of our conclusion is the assertion that, regardless of the differences among stock issues, there is something that is: "to a certain extent, fixed" (Houtlosser 2001, 39).

So, let us ask ourselves, once more: 'What kind of rationality do we talk about when our students are to become 'rational judges' through teaching of philosophy?' Moreover, we are not avoiding that all the above mentioned rationalities play a role in the argumentation of a problem. We tried to prove this by the previous interpretation, but: 'Is there any kind of rationality that unites all the others and which we place as a premise for critical thinking?' In looking for an answer to this question, we can look at one Husserl's distinction. Namely, Husserl does not have a single view of rationality, if we take into account his division, a priori categorization of the problem. In his lectures entitled The Idea of Phenomenology, he makes a distinction between two concepts of perceiving a priori. In the first place, he emphasizes the notion of a priori concerning the sphere of absolute gifts, but then immediately expands this notion to: "not only theoretical reason but also practical reason, and any other form of reason as well" (Husserl 1999, 39). On the other hand, Dilthey, who relies heavily on Husserl, speaks of: "the point where the appearance of a subordination of the matter of experience to a priori of forms and laws of thought vanishes completely" (Dilthey 2002, 31), which can actually be seen as a kind of 'theoretical reason' that will follow all other types of rationality, in order to establish communication as a prerequisite for critical thinking. So, the

${ }^{17}$ See: (Heidegger 2002, 59) 
theoretical basis from which we actually begin as a skill takes what Habermas calls 'communicative rationality' and which implies that:

\begin{abstract}
"An assertion can be called rational only if the speaker satisfies the conditions necessary to achieve the illocutionary goal of reaching an understanding of something in the world with at least one other participant in communication" (Habermas 1984, 11)
\end{abstract}

The other types of rationality that we have mentioned will take place at a higher level of perception, which, again on Dilthey's trace, can be defined as: "elementary operations such as comparing, combining, separating, relating" (Dilthey 2002, 31), especially in the 'related' domain of the concept being discussed.

\title{
HOW TO CONNECT ESSENTIALISM TO PERENNIALISM IN PRACTICE?
}

Obviously, when we talk about critical thinking, we attempt to 'facilitate judgements' in favor of 'publicly certified expertise'. So, we are dealing with the study of a certain pattern of reading and writing that needs to be structured in a certain way, and disciplined in order for it to be set in relation to the next aspect of critical thinking, determined as enculturation from this perspective. And although it can be concluded from the wider context that "essentialist educators emphasize instruction in natural science rather than non-scientific disciplines such as philosophy or comparative religion" (Paris n.d.), through the statement that "training students to read, write, speak, and compute clearly and logically" (Cohen 1999), a link with philosophy can still be established. Of course, we are dealing with the domain concerning Logic and Methodology as philosophical disciplines. It is clear that, especially when studying Logic, we cannot rely on originality and free expression of opinion. Therefore, it is necessary to bear a certain degree of rigidity and discipline in order for the opinion to be rendered understandable and possible for a higher level of critical thinking, i.e. also comparing pro et contra argumentation about certain concepts.

Since this has been previously noticed, such formal reading and expressing actually meets only one requirement of critical thinking, and it stays closed to the recognition of concepts, i.e. as it has already been mentioned it lacks an ethical depth. Naturally, this shortcoming can be noticed even when dealing with some other domains, such as aesthetic, ontological, etc., which can all be labeled in a much simpler manner as cultural domains. In order to avoid such sort of shortcomings, we need to use the perennial concept of education. It deals with the need to fulfill a goal set from this perspective as: "cultivation of the intellect is the highest priority in a worthwhile education" (Cohen 1999). From our point of view, to achieve enculturation defined as "the process of cultural transmission" (Gatchel 2010, 
12), it is necessary to make sure that the "curriculum focuses on attaining cultural literacy, stressing students' growth in enduring disciplines" (Cohen 1999).

The conclusion that presents itself based on the previous discussion favors the following approach to critical thinking. On the one hand, the approach needs to be sensitive to the formation of the structure of expression in the light of the universal understanding of the presented claims. On the other hand, it also assumes wider education in the direction of cultural concepts that find their purpose in more profound recognition of flaws or advantages of one group in favor of the other, and all in order to achieve better movement within a given society. That society today is largely cross-cultural.

\section{REFERENCES}

Alston, Kal. "Re/Thinking Critical Thinking: The Seductions of Everyday Life." Studies in Philosophy and Education (Kluwer Academic Publishers), 2001: 27-40.

Aristotle. Nichomachean Ethics. Cambridge: Cambridge University Press, 2004.

Ballantine, Glenda. Creativity and Critique. Subjectivity and Agency in Touraine and Ricoeur. Leiden, Boston: Brill, 2007.

Belenky, Mary Field, Blythe McVicker Clinchy, Nancy Rule Goldberger, and Jill Mattuck Tarule. Women s Ways of Knowing. The Development of Self, Voice and Mind. New York: Basic Books, 1997.

Bogdanovski, Mašan. „Primena misaonih eksperimenata u nastavi”. Elementi, časopis za promociju nauke, jesen 2018: 34-35.

Bowell, Tracy, and Gary Kemp. Critical Thinking. A Concise Guide. London and New York: Routledge, 2005.

Brentano, Franz. Psychology from an Empirical Standpoint. London-New York: Routledge, 1995.

Burgess, John P. Philosophical Logic. Princeton and Oxford: Princeton Univiersity Press, 2009.

Carr, Wilfred, and Stephen Kemmis. Becoming Critical. Education, Knowledge and Action Research. London: Routledge Farmer, 2004.

Cholbi, Michael. "Intentional Learning as a Model for Philosophical Pedagogy." Teaching Philosophy 30, no. 1 (March 2007): 35-58.

Cohen, LeoNora M. Educational Philosophies. 1999. https://oregonstate.edu/instruct/ ed416/PP3.html (accessed September 15, 2018).

Cottrell, Stella. Critical Thinking Skills. Developing Effective Analysis and Argument. Hampshire and New York: PALGRAVE MACMILLAN, 2005.

Descartes, Rene. A Discourse on the Method. Oxford, New York: Oxford University Press, 2006.

-. Meditations on First Philosophy. Oxford, New York: Oxford University Press, 2008.

- Regulae ad directionem ingenii - Rules for The Direction of The Natural Intelligence. Amsterdam-Atlanta: Rodopi, 1998.

Dilthey, Wilhelm. The Formation of the Historical World in the Human Sciences. Princeton, Oxford: Princeton University Press, 2002.

Dworkin, Ronald. Taking Rights Seriously. Cambridge: Harvard University Press, 1978. 
Evers, Colin W. "Culture, Cognitive Pluralism and Rationality." In Critical Thinking and Learning, by Mark Mason, 25-43. Oxford: Blackwell Publishing, 2008.

Galilej, Galileo. Spisi u odbranu Kopernikovog sistema. Beograd: Plato, 2010.

Gatchel, Richard H. "The evolution of the concept." In Concepts of Indoctrination, by I. A. Snook, 7-13. London and Boston: Routledge \& Kegan Paul, 2010.

Habermas, Jurgen. The Theory of Communicative Action, Reason and The Rationalization of Society. Boston: Beacon Press, 1984.

Hanson, Michael Hanchett. Worldmaking: Psychology and The Ideology of Creativity. New York : Palgrave Macmillan, 2015.

Hare, William. "Critical Thinking as an Aim of Education." In The Aims of Education, by Roger Marples, 85-99. London and New York: Routledge, 1999.

Heidegger, Martin. Of The Beaten Track. Cambridge: Cambridge University Press, 2002.

Houtlosser, Peter. "Points of View." In Crucial Concepts in Argumentation Theory, by Frans H. van Eemeren, 27-51. Amsterdam: Amsterdam University Press, 2001.

Husserl, Edmund. The Idea of Phenomenolgy. Dodrecht, Boston, London: Kluwer Academic Publishers, 1999.

Kant, Immanuel. Anthropology, History and Education. New York: Cambridge University Press, 2007.

Longman Dictionary of Contemporary English. https://www.ldoceonline.com/ (accessed December 25, 2016).

Macmillan Dictionary. https://www.macmillandictionary.com/british-and-americanpronunciation.html (accessed December 25, 2016).

Malmgren, Kimber W., Beverly J. Trezek, and Peter V. Paul. "Models of Classroom Management as Applied to the Secondary Classroom." The Clearing House 79, no. 1 (September/October 2005): 36-39.

Marinkovic, Josip. Filozofija kao nastava. Zagreb: Hrvatsko filozofsko društvo, 1990.

Mason, Mark. "Critical Thinking and Learning." In Critical Thinking and Learning, by Mark Mason, 1-11. Oxford: Blackwell Publishing, 2008.

Paris, N. A. Major educational philosophies. http://ksuweb.kennesaw.edu/ nparis/ educ7700/EDUCATIONAL\%20PHILOSOPHIES\%20(Major)_.doc (accessed September 15, 2018).

Paul, Richard W., and Linda Elder. Critical Thinking: Tools for Taking Charge of Your Professional and Personal Life. New Jersey: Financial Times Prentice Hall, 2002.

Phelan, Anne M. "The Death of a Child and the Birth of Practical Wisdom." Studies in Philosophy and Education (Kluwer Academic Publishers), 2001: 41-55.

Thayer-Bacon, Barbara J. "Radical Democratic Communities Always-in-the-Making." Studies in Philosophy and Education (Kluwer Academic Publishers), 2001: 5-25.

van Eemeren, Frans H., and Rob Grootendorst. Speech Acts in Argumentative Discussions. Dordrecht, Cinnaminsom: FORIS PUBLICATION, 1984. 


\title{
КРИТИЧКО МИШЉЕЊЕ ИЗМЕЪУ ЕСЕНЦИЈАЛИЗМА И ПЕРЕНИЈАЛИЗМА
}

\author{
Иван Николић \\ Универзите у Нишу, Филозофски факултет, Ниш, Република Србија
}

\section{Резиме}

Савремена наставна пракса у великој мери фаворизује критичко мишљење као врховни циљ образовања. За нас се истраживање овог концепта показало утолико интересантније уколико се пође од претпоставке да се овај концепт јавља у филозофији од самих њених почетака. Отуда, с обзиром на то да се не ради о универзално прихваћеном концепту, морали смо да већину истих поделимо у два табора. Један који фаворизује вештине и други који фаворизује став. Ипак, може се видети да ове крајности заправо крију извесне недостатке, који се могу помирити у виду једне шире образовне филозофије која се налази на граници између есенцијализма и перенијализма. У том светлу, концепција која фаворизује вештине остаје у недовољној мери осетљива на контекст, а она друга лако може упасти у вербални егзибиционизам. Есенцијализам као позиција која у први ред ставља дисциплину и структуру у изражавању ефикасно уклања недостатке другог табора, који на критичко мишљење, пре свега, гледа као на енкултурацију. Ипак, сама дисциплина и структурисање мишљења на начин логике и методологије, премда спречава вербалну егзибицију и омогућава универзално разумевање на површини комуникативног процеса, остаје ускраћено за разумевање неких проблема који су, пре свега, културно формирани. Тај недостатак превазилази се на начин укључивања перенијализма у образовни процес, а који подразумева образовање о различитим културним обрасцима који стоје иза одређених вредносних ставова. 